\title{
Homegarden Agroforestry as a Tool for Sustainable Production Unit in Ethiopia
}

\author{
Gonfa Kewessa \\ Department of Forestry, Ambo University, Ambo, ETHIOPIA. PO box 19, Ambo, Ethiopia
}

\begin{abstract}
Homegarden is the chief center of production unit in Ethiopia, particularly for the poor smallholder families. Homegarden is an area of land in the household's compounds and its surrounding's where different annual crops, livestock's and trees integrated and produced. In the rural part of Ethiopia, homegarden agroforestry has a paramount importance since ancient time. It has been providing different useful products and services to millions of rural households. On the top of these benefits, little attention was given to homegarden agroforestry rather than giving due attention on how to make it more productive unit of land. This review paper was initiated to draw attention of scholars and policy makers through elucidating the production potential and ecological importance of homegarden agroforestry (HGA). HGA encompasses multiple components (tree, crop, livestock's and etc), and intensive management practice with multistory production system based on the good will of the land user's, knowledge and skills. HGA provides different goods to the household families' including food/fruit, fuelwood, fodder, timber and other tree products. It also functions as in-situ conservation of biodiversity. Therefore, inclusion of appropriate multipurpose tree and shrub species is recommended to maximize the production potential of this unit of land.
\end{abstract}

Keywords: Multiple products, production and productivity, Livelihood mechanisms

DOI: $10.7176 / \mathrm{JRDM} / 67-02$

Publication date:July $31^{\text {st }} 2020$

\section{Introduction}

Ethiopia is one of the most highly populated countries in Africa with about 100 million people on 1.12 million $\mathrm{km}^{2}$ area of land. In Ethiopia, the essence of maintaining population-food-nutrition balance cannot be overlooked. An increasing population requires more tree products and cultivable lands (Abebaw, 2006). Increasing pressure of human and livestock population causes degradation of natural resources. Intensive agriculture tends to increase crop yield without natural resource conservation. Rapid increase in food crop production depends on the expansion of the areas under cultivation through removal of the patches of forest nearby (Zebene, 2003).

Population growth, increasing commercialization of products and the use of modern inputs are the most important factors that contribute to landuse changes. Recently, concerns have developed on the long-term sustainability and environmental consequences of the intensification of agricultural systems. Increasing attention is being given to achieving stability in land utilization on the longer term basis while fulfilling the needs of the local population (Reijntjes et al., 1992; Swift \& Ingram, 1996; Tilman et al., 2002; Matson et al., 2002). Notably, in small holder farming systems in the tropics, the use of modern technologies might not be the first option to improve agriculture.

Agroforestry is a new name for a set of old practices (Nair, 1993). Agroforestry offers a potential solution to the problem of declining rural agricultural production in the tropics (Jiregna, 1998). Agroforestry (AF) is a relatively new name for a set of old practices. Cultivating trees, agricultural crops and pastures and/or animals in intimate combination with one another spatially or temporally is an ancient practice that farmers have used throughout the world (Nair, 1989, 1993; Tolunay et al., 2007).

Homegarden are the most complex and diverse agro-ecosystems and this indicates their suitability to fulfilling ecological functions. On the forest-monocropping continuum, homegardens are located far from market oriented commercial production systems but this doesn't necessarily indicate that they are economically less attractive. On the contrary, many homegardens in the tropics are economically more viable than other land use systems in the regions because of the high-value cash crops comprised in them. Fernandes \& Nair (1986) define homegardens as 'landuse practices involving deliberate management of multipurpose trees and shrubs in intimate association with annual and perennial agricultural crops and invariably, livestock, within the compounds of individual houses, the whole crop-tree-animal unit being managed by the family labor. Homegardens are found throughout the tropics, but they are more common in the humid lowlands. In addition, they occur also in several tropical highland regions. Ethiopia is one of the tropical countries where homegardens are prevalent in the highlands. As indicated in Tesfaye (2005), the importance of homegardens to fulfill household needs for a variety of crops is acknowledged, but agricultural scientists have rarely been interested in them. For example, the following quote from Fernandes \& Nair (1986) could indicate why there is lack of interest among scientists. "Scientists who are not familiar with the homegardens do not realize the importance and potential contribution of these systems in the framework of agricultural or agroforestry developments. Some others, who are under the influence of the traditional outlook of monocultural systems of agriculture or forestry, consider the homegardens to be very specialized systems adapted 
to subsistence land use, or structurally too complex to be suitable as a model to work with". Hence, scientific attention has rarely been given to improve these traditional systems.

Homestead agroforestry/gardening, and especially the production of horticultural crops, can perhaps most effectively help to ensure food and nutritional securities in addition to self-employment, poverty alleviation and income generation of poor farmers. Human life had begun with gardens, and the fruits, vegetables, and roots that grew there in; man's livelihood on the earth had commenced with a collection of whatever products the trees and other plants of that time had borne - fruits, roots, leaves, shoots, and seeds (Ahmad, 1995).

Homegarden agroforestry systems in the tropics are known for their structural complexity and diversity in crop and other plant species (Michon et al., 1983; Fernandes \& Nair, 1986). Homestead agroforestry refers to intimate association of multipurpose trees and shrubs with annual and perennial crops, and, invariably, livestock within the compounds of individual houses, with the whole crop-tree-animal unit being managed by family labor (Fernandes \& Nair, 1986). It evolved through generations of gradual intensification of cropping in response to increasing human pressure and the corresponding shortage of arable lands (Kumar \& Nair, 2004). The cultivation of different crops is regarded as a strategy of farmers to diversify their subsistence and cash needs. Diversification also helps to stabilise yield or income in cases of incidences of disease and pests, and market price fluctuations. Moreover, the intimate association between the different herbaceous and woody components in these gardens is believed to enhance nutrient recycling and reduce hazards of leaching and soil erosion (Wiersum, 1982; Fernandes \& Nair, 1992).

The objective of this review article is to summarize the major functions homestead agroforestry towards household benefits with a view to visualize its importance and potential for future development. This objective has been addressed through examining the available published information and incorporating the experiences of the author.

\section{Homestead in Ethiopia}

Homestead agroforestry is an integral part of the livelihood strategies of rural households and, so far, the most ancient system of production in Ethiopia, regardless of ecosystems. Historically, households have been planting vegetables, fruits, and forest species, and rearing livestock in their homesteads at various micro-sites with a view to meet their various daily requirements. This is a supplementary food production system, which is under the management and control of household members, particularly the women. Another significant feature in homestead agroforestry is the active involvement of women. They play a major role in managing the homestead production apart from food preparation and other domestic activities of the family.

It is interesting to note that the commonest vernacular equivalent for the term homegarden, "yeguaro-atkilt" or "yeguaro-irsha", meaning the backyard crop/garden/farm in the Amharic language, nicely concurs with the most frequently observed type, i.e. backyard (Zemede \& Ayele, 1995). Another commonly used term for homegarden is the Afan Oromo term "edo" which is related to individual/private holdings. These names refer to farming systems that have persisted for centuries. Homesteads are variable with regard to species composition, management practices as well as the prevailing biophysical and socioeconomic environment. In most places, availability of space determines the position of the garden in relation to the house while the agro-ecological conditions, sociocultural factors and availability of the crop influence the species composition. In some areas, typical garden crops are grown in tightly fenced enclosures situated at distances of $1-4 \mathrm{~km}$ away from the homestead (Zemede \& Ayele, 1995). Crops and herbs that are utilized frequently and those requiring close supervision and protection are usually cultivated in close-to-home sites or inside the living compound. In rural and semi-rural settings of west shewa and Southern Nation's Nationalities and People Region, where extended homegardens are common, gardens are generally large in size.

They are associated almost with every house and contain relatively high and diverse number of crops. Homegardens in these areas (also known as the Enset complex or hoe-agriculture areas) mainly produce stable crops e.g. oromo dinich (Plectranthus edulis (Vatke) Agnew), yam (Dioscoria spp.), taro (Colocasia esculenta (L.) Schott.) and sweet potato (Ipomea batatas L.) Lam.), in addition to crops such as the Arabica coffee (Coffee arabica L.) and Enset (Ensete ventricosum (Welw.) Cheesm.). These plants are believed to have been domesticated in Ethiopia (Galparian, 1981) cited in Zemede \& Ayele (1995). The gardens serve as the primary food security strategy for farming communities and the neighboring peri-urban inhabitants. In the south, east and south-west, gardens give high economic returns through cultivation of important cash crops including chat (Catha edulis (Vahl) Forssk.ex Endl) and coffee (Coffee arabica L.).

Extensive areas of traditional agroforestry homegardens exist in the south and south-western parts of Ethiopia. Most of these gardens are located at altitudes of 1500-2300 meters above sea level where moisture and temperature conditions are favourable for agriculture. These gardens are characterized by a unique combination of two native perennial crops: enset and coffee. Enset (Enset ventricosum (Welw.) Cheesman) is a herbaceous multipurpose crop, and a staple food for about 10 million people in the region. Coffee (Coffea arabica L.) is mainly used as cash crop, but also for household consumption. Other components of these multi-species agro-ecosystems include chat 
(Chata edulis (Vahl.) Forssk. ex Endl.), a mild stimulant, root and tuber crops, fruits, vegetables, cereals, spices and other crops. Moreover, livestock are kept in the gardens and different tree species are grown to serve productive as well as ecological functions. These gardens are also known as 'enset-coffee homegardens' after the two major components.

According to the classification of agroforestry systems based on the nature and type of components, most homegardens are agrosilvopastoral systems consisting of herbaceous crops, woody perennials and animals and some are agrisilvicultural systems consisting only of the first two components (Nair, 1993). This is an agrosilvopastoral system under which a mixture of perennials, annuals and animals occur in combination very close to the homestead (Nair, 1993). Tropical homegardens consists of an assemblage of plants which may include trees, shrubs, vines, and herbaceous plants, growing in or adjacent to a homestead or home compound and these gardens are planted and maintained by members of the household (Nair, 1993). Homegardens are of economic importance to small farm families because they provide supplementary and continuous flow of products such as food for household consumption, medicine, poles, and offer a buffering capacity when the main crops fail (Soemarwoto and Conway, 1991; Torquebiau, 1992; Nair 1993); the gardens also have considerable ornamental value, and they provide shade to people and animals (Nair, 1993).

\section{Functions of the Homestead Agroforestry}

\subsection{Homestead Agroforestry: A System for Multiple Products}

Historically, homestead agroforestry production system has been providing multiple products to the households and meeting their diversified need through the production of a wide variety of fruits, vegetables, spices, and different tree products (Miah et al. 2002). Homegardens are multispecies agroecosystems where different herbaceous and tree crops as well as trees are managed in integration. Diversity of species of crops, trees and livestock in homegardens has several ecological and socioeconomic benefits. Three main components of biodiversity can be distinguished in homegardens; crops, trees and livestock.

Trees and shrubs are very important components of homegardens, as they play multiple roles in the systems. They provide the households with wood products and cash, and also play a role in maintaining and enhancing the physical environment needed to sustain crop production. Trees provide firewood, which is the major energy source in most developing countries. Furthermore, trees provide wood for various local uses, such as housing construction, fencing, furniture, household utensils and farm tools. Trees also provide other products such as fodder, human and livestock medicine, food and they serve as bee forage. Furthermore, trees are increasingly becoming important income sources for many farmers in rural areas, mainly because the wood can be sold as timber or as firewood. In addition to fulfilling the material needs of the farming community, trees play important ecological roles in agricultural systems. These roles include nutrient cycling, provision of mulch, nitrogen fixation (some of them), and service as shade, wind breaks and erosion control. These functions help to maintain and improve soil fertility, regulate soil moisture and temperature, and improve the microclimate eventually contributing to the stability and resilience of the systems. Therefore, the presence in farms of diverse tree species that serve different socioeconomic and ecological functions could contribute to sustainability of agricultural systems.

\subsection{Homestead Agroforestry: A Source for Nutrition, Employment, and Biodiversity Conservation 3.2.1. Homestead Agroforestry: An Excellent Source of Nutrition}

Nutritional problem is the key issue along with food security in Ethiopia today. A small percentage of the people have access to nutritious food, whilst the majority is forced to survive on subsistence diets that are unbalanced and devoid of essential food ingredients (MoA-UNPD, 2000). Generally, landless and marginal farmers are at more risk nutritionally than larger households. These households have lower per capita grain availability and higher rates of child malnutrition (Talukder et al., 1997). Of all the options available to tackle national malnutrition problem, the most practical and sustainable option would be to promote both cultivation and consumption of horticultural crops (fruits, vegetables, and spices) that could provide basic requirement of the essential vitamins and minerals.

The homegardens contribute a great deal to food supply especially for the people living in the rural areas because of high production and diversity of cultivated edible species. Although the extent of household dependency on homegardens varies considerably, its contribution is quite significant towards livelihood of the people because of low investment and easy accessibility. Homegardens function as ex situ as well as in situ conservation plots for plant genetic resources of the region. For instance, production of horticultural crops especially vegetable and fruits were reported to be the answer to the potential problems of hunger and malnutrition in Bangladesh (Javier, 1992; Ahmad, 1995).

\subsubsection{Homestead Agroforestry: A Platform for Employment and Economic Security}

A vast majority of rural people in Ethiopia who cultivate land for crop production remains unemployed for a considerable period of the year because of seasonality of production activities and labor requirements. Homestead farming is the best answer to such unemployment situation through both vegetable growing, and culture of quick 
growing fruits enabling the people to remain employed round the year (Ahmad, 1995). It has been found that over the decades, small-scale homestead activities have become the most significant income generating activities of poor households. Das \& Das (2005) reported that homegarden systems provide an additional food supply and cash income for the people.

Homegardens are a vital source of income for subsistence economy and contribute to the self-sufficiency of many rural households perched in remote places often secluded from markets and modern production centres. This is also true for the homegardens in other tropical countries (Kumar \& Nair 2004; Peyre et al., 2006). The people usually work in the homegardens during leisure time or after coming back from agriculture fields or early in the morning before going to the field.

\subsubsection{Homestead Agroforestry and Management: A Key Employment Opportunity for the Women}

Women, the vulnerable group of the society and half of the country's population, have a great opportunity for selfemployment in the income-generation activities through the practice of vegetable and fruit production in the homestead. Homestead agroforestry activities are keeping busy the entire households particularly the women who have minimum opportunities to be involved with other than homestead activities and ensuring the economic security especially to the poorer. The possibility of gender equality for participating in home garden management and sharing of benefits is perhaps one of the major stimuli for continued household food security enjoyed by home gardeners (Kumar \& Nair, 2004). Homestead being the dwelling place, enables the women for efficient management of homestead activities. Use of family labor, especially women labor, in the production process not only satisfies a wide range of domestic needs more economically but also ensures lowering of production costs and ultimately promotes more income.

In Ethiopia, women were once mostly involved in the household activities particularly in taking care of children and other family members, preparing and serving food to members of the household. Women are deeply involved in the process of homestead farming from sowing to harvesting, processing and marketing of products (Chowdhury et al., 1992). The major labour input is contributed by women (Sultana, 1993) despite of the fact that every member of the family has roles in homestead farming. Their roles vary widely depending upon the socioeconomic and religious factors. It has been shown that female labors of landless families gave the maximum time compared to other categories of families (Nessa et al., 1998). According to Akther (1990), women with their various homestead production activities such as seedling raising, small-scale animal, poultry rearing, etc., increase family income.

\subsubsection{Homestead Agroforestry: A Pathway for Plant Biodiversity Conservation}

Agricultural biodiversity (agrobiodiversity) is defined as the variety and variability of plants, animals and microorganisms at genetic, species and ecosystem level involving the whole agro-ecosystem that is actively managed by farmers (Cromwell et al., 1999). Plant biodiversity is the plant genetic wealth of a country or an area. Ethiopia once was endowed with thousands of diverse species, but its rich biodiversity is on the verge of rapid decline, because the current rate of extinction of different species is many times faster than what it would have been through the natural process because of rapid depletion of natural forest coverage and mono-cropping with high yielding and hybrid varieties.

One of the typical features of tropical homegardens is the high diversity of their components. As cited in Tesfaye (2005), the high diversity of species in homegardens is considered as an essential component of sustainable agriculture because of the wide socioeconomic and ecological roles. These roles include:

$\checkmark$ year round production of food and a wide range of other products such as firewood, fodder, spices, medicinal plants and ornamentals (Wiersum, 1982: Fernandes \& Nair, 1986; Soemarwoto, 1987; Gliessman, 1990).

$\sigma$ decreased risks of production failure, increased resource productivity over time, expansion of the amount and quality of labor applied in the farm (Netting \& Stone, 1996), and provision of output flexibility and alternative production should unfavorable circumstances develop (Wojkowski, 1993).

$\checkmark$ potential to serve as repositories of genetic diversity, besides acting as insurance against pests and disease outbreaks, which may be very severe in monocultural stands (Michon et al., 1983).

$\sigma$ avoidance of environmental deterioration commonly associated with monocultural production systems (Fernandes and Nair, 1992), largely due to effective nutrient cycling and relatively small hazard for leaching and soil erosion (Wiersum, 1982; Jensen, 1993).

$\checkmark$ provision of materials for breeding of useful new crop varieties (Cromwell et al., 1999).

$\checkmark$ wider ecological services such as landscape protection, soil protection and health, water cycle and quality and air quality (Cromwell et al., 1999).

The homegardens in Ethiopia contain different life forms, species and varieties. Homestead agroforestry offer the best option to conserve the diverse range of biodiversity. It is the in-situ conservation site of a wide range of plant biodiversity, which is characterized by the measures of species richness, relative prevalence, and inter- and intra-species diversity (Heyhood \& Watson, 1995). Homestead agroforestry practice, being a multi-strata production system where diverse plant species are grown in intimate association with or without animals could be a potential option for conservation of biodiversity. A large number of higher plants have been recorded in 
homesteads and rural areas of Ethiopia. Indeed, in designing homestead agroforestry system, emphasis should be given to include indigenous species since these are ecologically best suited and economically viable.

\subsection{Major Issues for Sustainable Production System}

Agricultural sustainability is defined as 'the successful management of resources for agriculture to satisfy changing human needs while maintaining or enhancing the quality of the environment and conserving natural resources' (CGIAR, 1988). In order to improve the overall productivity of the homestead agroforestry, there is a need to identify suitable species in terms of matching and growth performances to the micro-sites of the homesteads; availability of quality planting materials and their easy propagation; development of pruning and thinning regimes of the individual species; protection measures against the major pests and diseases; optimum rotation period on the basis of cost-benefit analysis; study prevailing wood market structure and agroforestry enterprises in order to promote necessary linkages with industries and trade for employment and income generation of the rural people, particularly for the women.

\section{Conclusion}

Homegardens are an important element of rural landscape of many tropical countries including Ethiopia. Homegardens enhance the livelihood of the people by providing food, construction materials, medicines and by contributing to the gross annual income of the household. The review cited in this paper on different aspects of homestead agroforestry production system revealed that it appeared a potential area for improving production and income of the rural households of Ethiopia. The paper clearly stated how homestead agroforestry meets the diversified needs of the rural households through production of a wide variety of agricultural (food crops, vegetables, spices, fodder, etc.) and forest/tree products (fruits, timber, fuelwood, etc.) as well as medicinal plants. Though the homestead agroforestry production system in Ethiopia has been playing important role in rural economy of Ethiopia from the time immemorial, but the pressure of the ever-increasing population on homestead land and the rapidly changing social and economic conditions of the people pose a threat to the sustainable development of homestead agroforestry system. Thus, there is a need to conduct in-depth research and development activities on homestead agroforestry in special consideration of the smallest resource bases (microsites) of the subsistence farmers in order to work out different options and to facilitate more optimum use of the available resources of the poor farmer for meeting the future challenges.

\section{References}

Abebaw, Z. (2006). Farmers indigenous knowledge in managing agroforestry practices in Lay-Gayint district, south Gonder zone, Ethiopia, MSc Thesis, Hawssa Vniversity, wondogent, pp. 82

Ahmad, K. U. (1995). Vegetable crops business in Bangladesh. A consultancy report under AVRDCBARC/BARIUSAID Bangladesh project, BARI, Gazipur, Bangladesh.

Ahmed, M. F. U. (1999). Homestead agroforestry in Bangladesh: A case study of Gazipur district. A master of science dissertation in Agroforestry and Environment. Department of Agroforestry and Environment, Bangabandhu Sheikh Mujibur Rahman Agricultural University, Gazipur, Bangladesh.

Akther, A. (1990). Involvement of women in homestead production in a selected village of Tangail district. A Master of Science dissertation in Agriculural extension and education, Bangladesh Agricultural University, Mymensingh.

Ali, M. M. (2003). Women's participation and contribution on homestead agroforestry production activities: A case study at Bogra district. A Master of Science dissertation in agroforestry. Department of Agroforestry, Bangladesh Agricultural University (BAU), Mymensigh, Bangladesh.

CGIAR (Consultative group on International Agricultural Research). (1988). Sustainable Agricultural Production: Implications for International Agricutural research, FAO, Rome.

Chowdhury, M. K., Islam, M. A., \& Satter, M. A. (1992). Homestead vegetable production in Bangladesh. In: Proceedings of a workshop on Vegetable production and marketing, AVRDC, pp 64-77.

Das, T, \& Das, A. K. (2005). Inventorying plant biodiversity in homegardens: A case study in Barak Valley, North East Assam. Current Science, 89: 155-163.

EMA (Ethiopian Mapping Agency). (1988). National Atlas of Ethiopia. Addis Ababa, Ethiopia.

Fernandes, E. C. M. \& Nair, P. K. R. (1986). An evolution of the structure and function of tropical homegardens. Agricultural Systems 21: 279-310

Galparian, G.. (1981). Ethiopia: Population, Resources, economy. Progress publishers. Moscow. 141-143.

Heyhood, V. H., \& Watson, R. T. (1995). Biodiversity assessment. UNEP, Cambridge University Press, pp 5-105.

Jiregna, G.. (1998). Decomposition and Nutrient release from leaves of croton macrostachyus and millettia ferruginea for soil improvement in agroforestry system. Msc thesis, Skinnskatteberg, ISSN 1402-201X.

Kumar, B. M., \& Nair, P. K. R. (2004). The enigma of tropical homegardens. Agroforestry Systems, 61: $135-152$. Matson, P. A., Parton, W. J., Power, A. G., \& Swift, M. J. (2002). Agricultural intensification and ecosystem 
properties. Science 277: 504.

Michon, G.., Bompard, J., Hecketsweiler, P., \& Ducatillon, C. (1983). Tropical forest architectural analysis to agroforests in the humid tropics: The examples of traditional village-agroforests in west Java. Agroforestry Systems 1: 117-129.

Nair, P. K. R. (1989). Agroforestry systems in the tropics, Kluwer Academic publisher, The Netherlands, vol.31 pp.13

Nair, P. K. R. (1993). An introduction to agroforestry, Kluwer Academic publisher, Dordrecht, The Netherlands.

Nessa, J. S. K., Hossain, S. M. A., \& Fouzder, S. K. (1998). Participation of family members in homestead and off-farm activities according to gender differences. Bangladesh J Ext Ed 10(1 and 2):81-85.

Peyre, A., Guidal, A., Wiersum, K. F., \& Bongers, F. (2006). Dynamics of homegarden structure and function in Kerala, India. Agroforestry Systems, 66: 101-115.

Reijntjes, C., Haverkort, B., \& Waters-Bayer, A. (1992). Farming for the future: An introduction to low-externalinput and sustainable agriculture. ILEIA, Leusden, The Netherlands.

Soemarwoto, O. \& Conway, G. R. (1991). The Javanese homegarden. J. Farming Systems Research - Extension 2(3): $95-117$.

Sultana, P. (1993). Gender roles in agricultural production and crop diversification programme. Paper presented at workshop on social and gender analysis and gender awareness building, held during 1-2 December, Dhaka, Bangladesh.

Swift, M. J. \& Ingram, J. S. I. (1996) (eds). Effects of global change on multi-species agro-ecosystems. Global change and terrestrial ecosystems, Report no. 13, GCTE Activity 3.4, GCTE Focus 3 Office, Wallingford, UK.

Talukder, A., Khan, T. A., Baker, S. K., Zakaria, A. K. M., Bloem, M. W., Kiess, L. K. (1997). Home gardening activities in Bangladesh. In: Satter S (ed) Mapping report and inventory. Helen Keller International, Incorporated. ISBN: 984-8185-04-8.

Tesfaye, A. (2005). Diversity in home garden agroforestry systems of southern Ethiopia. PhD Thesis Wagenineg University \& Research center. The Nether lands. Pp.143.

Tilman, D., Cassman, K. G., Matson, P. A., Naylor, R. \& Polasky, S. (2002). Agricultural sustainability and intensive production practices. Nature, 418: 671-677.

Tolunay, A., Alkan, H., Korkmaz, M., \& Filizbilgin, S. (2007). Classification of traditional agroforestry practices in turkey. International journal of Natural and Engineering science 1(3):41-48.

Torquebiau, E. (1992). Are tropical agroforestry homegardens sustainable? Agriculture Ecosystems and Environment, 41: 189-207.

Wiersum, K. F. (1982). Tree gardening and Taungya on Java: examples of agroforestry techniques in the humid tropics. Agroforestry Systems 1: 53-70.

Zebene, A. (2003). Tree species diversity, Top soil conditions and Arbuscular mycorrhizal Association in the Sidama Traditional agroforestry land use, southern Ethiopia, Doctorial Thesis. Department of Forest management and products, SLU. Acta Universitatis Sueciae. Silverstria, pp. 263.

Zemede, A., \& Ayele, N. (1995). Homegardens in Ethiopia: characteristics and plant diversity. SINET: Ethiopian Journal of Science 18: 235-266. 